2020-2030 Strategy for the National Cooperative Geologic Mapping Program

Renewing the National Cooperative Geologic Mapping Program as the Nation's Authoritative Source for Modern Geologic Knowledge

Open-File Report 2021-1013 



\section{Renewing the National Cooperative Geologic Mapping Program as the Nation's Authoritative Source for Modern Geologic Knowledge}

By John Brock, Karen Berry, James Faulds, Richard Berg, Kyle House, Michael Marketti, Darcy McPhee, Kevin Schmidt, James Schmitt, David Soller, David Spears, Ren Thompson, Harvey Thorleifson and Gregory Walsh

2020-2030 Strategy for the National Cooperative Geologic Mapping Program

Open-File Report 2021-1013 


\section{U.S. Geological Survey, Reston, Virginia: 2021}

For more information on the USGS - the Federal source for science about the Earth, its natural and living resources, natural hazards, and the environment—visit https://www.usgs.gov or call 1-888-ASK-USGS.

For an overview of USGS information products, including maps, imagery, and publications, visit https://store.usgs.gov/.

Any use of trade, firm, or product names is for descriptive purposes only and does not imply endorsement by the U.S. Government.

Although this information product, for the most part, is in the public domain, it also may contain copyrighted materials as noted in the text. Permission to reproduce copyrighted items must be secured from the copyright owner.

Suggested citation:

Brock, J., Berry, K., Faulds, J., Berg, R., House, K., Marketti, M., McPhee, D., Schmidt, K., Schmitt, J., Soller, D., Spears, D., Thompson, R., Thorleifson, H., and Walsh, G., 2021, Renewing the National Cooperative Geologic Mapping Program as the Nation's authoritative source for modern geologic knowledge: U.S. Geological Survey Open-File Report 2021-1013, 10 p., https://doi.org/10.3133/ofr20211013.

ISSN 2331-1258 (online) 


\section{Acknowledgments}

This strategic plan arose from a workshop convened in Lakewood, Colorado, by the National Cooperative Geologic Mapping Program during August 2016. The workshop was attended by representatives of the U.S. Geological Survey (USGS), State geological surveys, universities, and the National Park Service, all of whom contributed to defining the goals set out in this document. In addition to those participants, the authors thank the many geoscientists in State and Federal government organizations who contributed to discussions about the future of geologic mapping in the United States. This report also incorporates the suggestions proposed by three reviewers: Jon Hagstrum and Christopher Swezey of the USGS and Jonathan Arthur of the Florida Geological Survey. 



\section{Contents}

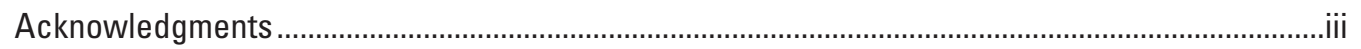

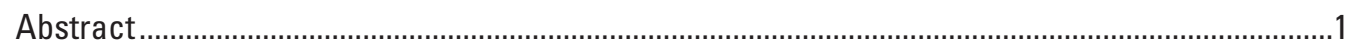

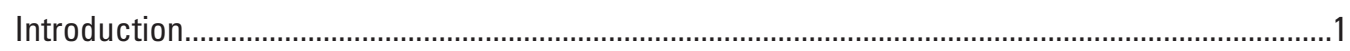

The National Cooperative Geologic Mapping Program Structure ……..........................................

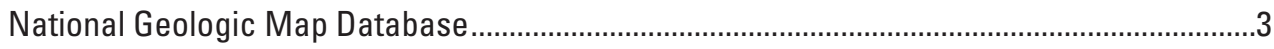

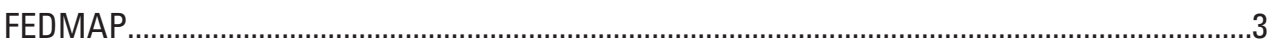

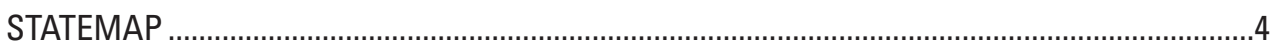

EDMAP

Renewed Vision, Mission, and Goals for the National Cooperative Geologic
Mapping Program.

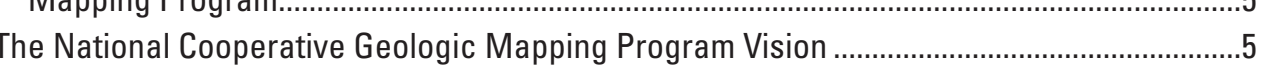

The National Cooperative Geologic Mapping Program Mission .................................................

National Cooperative Geologic Mapping Program Goals for a Renewed Vision ......................5

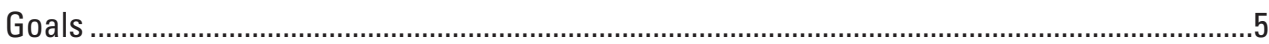

Achieve excellence in the performance and relevance of the FEDMAP,

STATEMAP, and EDMAP program components, and maximize

beneficial partnering between all program components ......................................5

Achieve preeminence in the use of field, remote-sensing, and geophysical

technologies, and construct the geospatial infrastructure required to

house a variable-scale, national, integrated $2 \mathrm{D}$ and $3 \mathrm{D}$ geologic model ............6

Populate the geospatial infrastructure defined under the second goal to create a variable-scale, national, integrated $2 \mathrm{D}$ and $3 \mathrm{D}$ geologic-framework model that enables the seamless construction of geologic maps within user-defined regions of interest across the United States by the year $2030 \ldots \ldots . .6$

Realizing the New National Cooperative Geologic Mapping Program Vision..................................6

Required Strategic Actions .............................................................................................

Actions With Program-Wide Relevance ..........................................................................

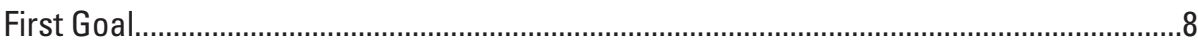

Achieve excellence in the performance and relevance of the FEDMAP,

STATEMAP, and EDMAP components, and maximize the beneficial partnering between all program components................................................

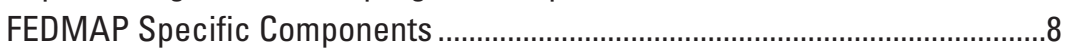

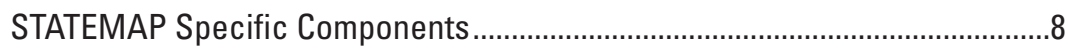

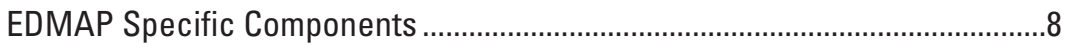

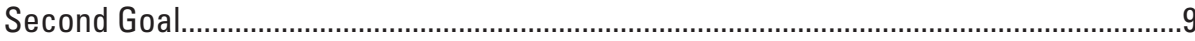

Achieve preeminence in the use of field and remote sensing and geophysical technologies, and construct the geospatial infrastructure required to house a variable-scale, national, integrated 2D and 3D geologic model.......................................................

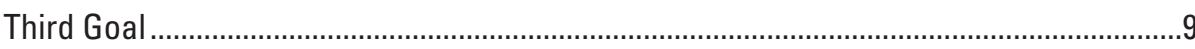

Populate the geospatial infrastructure defined under the second goal to create a variable-scale, national, integrated $2 \mathrm{D}$ and $3 \mathrm{D}$ geologic-framework model that enables the seamless construction of geologic maps within user-defined regions of interest across the entire United States by 2030 .........................................9

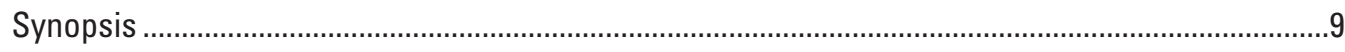

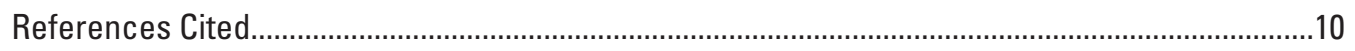




\section{Abbreviations}

$\begin{array}{ll}\text { 2D } & \text { two dimensional } \\ \text { 3D } & \text { three dimensional } \\ \text { AASG } & \text { Association of American State Geologists } \\ \text { COGEOMAP } & \text { Federal-State Cooperative Geologic Mapping } \\ \text { CSS } & \text { Core Science Systems } \\ \text { DMT } & \text { digital mapping techniques } \\ \text { DOI } & \text { U.S. Department of the Interior } \\ \text { GeMS } & \text { Geologic Map Schema } \\ \text { GIS } & \text { geographic information system } \\ \text { lidar } & \text { light detection and ranging } \\ \text { NCGMP } & \text { National Cooperative Geologic Mapping Program } \\ \text { NGMDB } & \text { National Geologic Map Database } \\ \text { USGS } & \text { U.S. Geological Survey }\end{array}$




\title{
Renewing the National Cooperative Geologic Mapping Program as the Nation's Authoritative Source for Modern Geologic Knowledge
}

\author{
By John Brock, ${ }^{1}$ Karen Berry, ${ }^{2}$ James Faulds, ${ }^{3}$ Richard Berg, ${ }^{4}$ Kyle House, ${ }^{1}$ Michael Marketti, 1 \\ Darcy McPhee, ${ }^{1}$ Kevin Schmidt, ${ }^{1}$ James Schmitt, ${ }^{5}$ David Soller, ${ }^{1}$ David Spears, ${ }^{6}$ Ren Thompson, ${ }^{1}$ \\ Harvey Thorleifson, ${ }^{7}$ and Gregory Walsh1
}

\section{Abstract}

This document presents the renewed vision, mission, and goals for the National Cooperative Geologic Mapping Program (NCGMP). The NCGMP, as authorized by the National Cooperative Geologic Mapping Act of 1992 (Public Law 102-285, 106 Stat. 166 and its reauthorizations), is tasked with expediting the production of a geologic database for the Nation based on modern geologic maps and their supporting data. In addition to highlighting the benefits of geologic maps for economic prosperity, national security, and environmental quality, the report describes the NCGMP structure and components. A renewed vision and mission for the NCGMP are stated, and three goals for guiding the program toward that vision for the next ten years are established. The vision of creating an integrated, three-dimensional, digital geologic map of the United States and its territories to address the changing needs of the Nation by 2030 is thereby defined to drive the activities of all NCGMP components for the next ten years. The strategic actions required to realize the NCGMP vision are identified for each of its components.

\section{Introduction}

More than two centuries after the 1815 publication of William Smith's landmark geologic map of England and Wales, geologic mapping remains a core activity of geological

\footnotetext{
IU.S. Geological Survey.

${ }^{2}$ Colorado Geological Survey.

${ }^{3}$ Nevada Bureau of Mines and Geology.

${ }_{4}^{4}$ Illinois State Geological Survey.

${ }^{5}$ Montana State University.

6Virginia Department of Mines, Minerals and Energy.

${ }^{7}$ Minnesota Geological Survey.
}

surveys worldwide. Land-use managers increasingly rely on geologic maps to return societal and economic benefits (Bernknopf and others, 1993; Bhagwat and Ipe, 2000) such as lives saved, hazards mitigated, resources discovered, infrastructure developed, costs avoided, and efficiencies increased. Understanding the Earth's composition, structure, and history through geologic mapping is at the forefront of basic and applied geologic research. Geologic maps are essential sources of foundational knowledge for economic prosperity, national security, and environmental quality. The National Geologic Mapping Act of 1992 (Public Law 102-285, 106 Stat. 166 and its reauthorizations) underscores our Nation's commitment to geologic mapping, mapping-based research, and the expeditious production of an integrated, accessible, geologic map database for the Nation.

In 1992, the 102nd U.S. Congress proclaimed that "geologic maps are the primary data base for virtually all applied and basic earth-science investigations [...]" (Public Law 102-285, 106 Stat. 166, (2)(a)(2)). From an historical perspective, all existing geologic maps represent such a database as they commonly include topographic features, geologic units and contacts, geologic structures, point data, and a wide variety of content in map explanations and related publications. Presently, much of the supporting information is referred to as "metadata." While Congress's proclamation sets the stage for the development of a geologic map database, an historical note is also required, because the concept of a "database" has evolved since 1992 because of significant technological advancements in the software, hardware, and visualization capabilities for managing and portraying large datasets. Modern geologic databases include more than published maps and supporting metadata elements. While metadata have always been part of a geologic map, current supporting data can be voluminous.

Since 1992, the U.S. Geological Survey (USGS) National Geologic Map Database (NGMDB) has been a congressionally mandated part of the National Cooperative Geologic Mapping Program (NCGMP) that delivers and archives geologic maps, merges published geologic maps into a single 
database, and develops standards and guidelines for map and database content. The cooperative effort between the USGS and State geological surveys, which has existed for many years, illustrates the success of this concept realized in a national, distributed geologic map database: the NGMDB.

In addition to serving as a source for basic metadata, the geologic map database must be expanded into an enterprise data system that contains national, regional, and detailed geologic-framework models that are managed according to content and format specifications. In this form, the expanded database must encompass all data that support geologic mapping and three-dimensional (3D) geologic modeling, to include-

- topographic data that represent the Earth's surfaceparticularly light detection and ranging (lidar) enhanced topography;

- structural contours (depths to a geologic surface from a given datum), isopach contours (thicknesses), and boundaries of surface and subsurface mapping units;

- the topography of the basement (Precambrian or as defined regionally) and the characterization of basement properties and selected structures as needed; and

- the physical and chemical properties of the materials between the land surface and basement.

Consequently, the components of the National Cooperative Geologic Mapping Program - the NGMDB and the FEDMAP, STATEMAP, and EDMAP programs - share a collective responsibility, as outlined in the National Geologic Mapping Act of 1992, to expedite the production of a geologic database for the Nation. In this way, geologic maps that contain information applicable to land-use management; assessment, utilization, and conservation of natural resources; groundwater management, and environmental protection can be developed. Additionally, the USGS determined that the NCGMP shares responsibility with other USGS programs to-

- identify and mitigate natural or human-induced geologic hazards to minimize property loss;

- provide for the health and safety of the general public; and

- facilitate the security and economic growth of the Nation.

A comprehensive roadmap for USGS science, as outlined in USGS Circular 1369, "Geology for a Changing World 2010-2020: Implementing the U.S. Geological Survey Science Strategy," identifies as its first goal to "Characterize and Interpret the Geologic Framework of the Earth through Time" (Gundersen and others, 2011, p. 1). The report states that

"The first goal of this report focuses on understanding the geology and history of the Earth through time. The emphasis is on creating an integrated, fourdimensional, digital framework for the Earth that incorporates data from the many subdisciplines of geology, such as tectonics, sedimentology, geophysics, paleontology, and geochemistry. Such a framework currently does not exist and will require new process-oriented research and mapping, interpretation and modeling, extensive collaboration with external partners, and data integration tools and technology. The knowledge provided by this framework will be essential to successful implementation of each of the strategic directions of the USGS science strategy (U.S. Geological Survey Circular 1309) and will form a strong foundation for future generations of scientists" (U.S. Geological Survey, 2007; Gundersen and others, 2011).

Additionally, the USGS Core Science Systems (CSS) mission area establishes a geologic-framework characterization of the Earth's lithosphere as the foundational component for understanding what is called the "critical zone" (Bristol and others, 2013), which is viewed as the vital interface between the physical Earth and the human environment.

Inherent in applied earth-science research is the recognition that robust geologic datasets are required to support all geologic maps, from the traditional two-dimensional (2D) maps of land-surface deposits to complex 3D geologicframework and synthesis models, as well as derivative products designed to address many resource and societal issues. Mapping is sometimes conducted with specific research objectives in mind but also with a general consideration of wideranging geologic problems. Consequently, the development of a national-scale geologic map requires a thematic focus on regional framework problems, regional geologic synthesis and process-oriented earth-science investigations, and the timely, effective, public dissemination of research and interpretive geologic mapping results.

The definition of a geologic map has changed and even varies across the discipline. Some traditionalists regard a geologic map as a 2D representation that conveys the attributes of the uppermost rocks, including composition, geometry and geographic distribution, origin, and age. Others view geologic maps as 3D depictions of earth materials and the redistribution of constituents over time (such that they can be applied to groundwater modeling). The NCGMP respects the many definitions of - and different historical perspectives on-geologic maps. However, the NCGMP aspires to define a "geologic map" as one supported by robust databases that contain a (lithology-based) material-properties framework model of geologic features and strata. Such geologic maps should be regularly updated, well-coordinated, multiresolution, seamless, $3 \mathrm{D}$ products from which customized and user-friendly maps can be derived. 


\section{The National Cooperative Geologic Mapping Program Structure}

The NCGMP has four "components": NGMDB, FEDMAP, STATEMAP, and EDMAP. These components, except for the NGMDB, fund competitively sourced, peer-reviewed project proposals. The FEDMAP component funds USGS scientists, while STATEMAP and EDMAP provide funding through external cooperative agreements with the State and academic partners, respectively, of the USGS.

As identified in the National Geologic Mapping Act of 1992, the USGS is the lead Federal agency for-

- establishing national geologic mapping program priorities;

- planning, coordinating, and funding FEDMAP projects;

- facilitating and funding intrastate program needs through the STATEMAP proposal process; and

- supporting EDMAP in relation to Federal and State mission requirements.

Aside from the NGMDB, the program components are administered independently, with review panels that annually consider mapping and research proposals for each component. The efficient use of current funding and the pursuit of targeted opportunities for future program growth are enhanced by coordination and communication between program components. This approach taps the strengths of Federal, State, and academic partners through an awareness of the multifaceted Congressional mandate ascribed to the NCGMP. Since 2007, funding for the NCGMP has varied between approximately \$24.4 million (the current level) and \$28.2 million per year. The approximate distribution of funding for the three NCGMP geologic mapping components has historically been 69 percent for FEDMAP (including NGMDB), 29 percent for STATEMAP, and 2 percent for EDMAP.

\section{National Geologic Map Database}

The implementation of standardized geologic mapping and more easily accessible geologic maps is facilitated by the NGMDB, which is managed by the USGS, in cooperation with the Association of American State Geologists (AASG). These implementations are conducted under proven, successful arrangements for the administration of data, stratigraphic names, and mapping standards. The Geologic Mapping Act of 1992 and its subsequent reauthorizations mandated creation of the NGMDB, which functions as a core element of the NCGMP office; it delivers the collected geospatial products that result from NCGMP-sponsored geologic mapping. The NGMDB implementation is carried out through three ongoing, continuously updated phases. Phase 1 is focused on building a single database by merging and integrating information from existing geologic maps and reports with stratigraphic nomenclature - the outcome is a map catalog or database of map coverages. Phase 2 addresses the development of schemas, standards, and guidelines for geologic maps and databases. Phase 3 builds upon the content, standards, and management of Phases 1 and 2 to develop a geologic-framework model database that includes line, point, and other vector data, in addition to national, regional, and detailed geologic map coverages. Phase 3 includes the design and implementation of an enterprise geographic information system (GIS) database for geologic mapping that is capable of housing geologic data, vector coverages, metadata, and base layers to let a multitude of users manage, share, and distribute the data to accommodate a wide range of information needs.

\section{FEDMAP}

The FEDMAP component of the NCGMP contributes to - and works within - the guidelines and science priorities established by the U.S. Department of the Interior (DOI) and USGS strategic plans. Geologic information is a foundational component of the strategic goals for the CSS mission area (Bristol and others, 2013; Association of American State Geologists, 2014). The program objectives are to develop a greater understanding of the national geologic framework through the development of geologic maps and complementary geochronologic and paleontologic data. Detailed geologic mapping is the best way to collect, synthesize, and portray geologic information and to identify geologic hazards, critical industrial and strategic mineral resources, potable water, and areas vulnerable to variable, and often interconnected, natural processes. Because of these essential qualities, geologic mapping is a primary activity of the CSS mission. Within this mission, the FEDMAP component of NCGMP is tasked with guiding and supporting the continued development of geologic maps for the Nation, based on the priorities established through the program council, opportunities presented through new USGS initiative funding, and the actionable priorities determined by the USGS Director, mission area associate director, and program coordinator. Priority is given to areas of compelling need, the needs of the land management agencies of the DOI, and areas where joint State-Federal geologic mapping projects are in the national interest.

The FEDMAP component of the NCGMP is dedicated to the development of regional geologic expertise and diverse research teams, with integrated skillsets, to produce interpretive geologic mapping of the highest quality. Through FEDMAP projects, the current program accelerated research in geologic specialties, including subsurface geophysical methodology and modeling, 3D geologic modeling, radiogenic isotope and cosmogenic geochronology, petrology and geochemistry, hydrogeology, and paleoenvironmental studies that support interpretive geologic mapping expertise. Significant project resources are dedicated to the production of new geologic maps, the reinterpretation and improvement of existing geologic maps, associated subsurface interpretations, 
and 3D model construction. Current FEDMAP projects within the NCGMP conduct mapping that enables applied research on wide-ranging, societally relevant topics that include-

- the development of 3D geologic models for hazard mitigation, predictive land- and water-use planning, and hydrologic modeling of critical groundwater basins;

- the development of subsurface data and the associated geologic synthesis of geologic hazards (for example, landslides and earthquakes), and of energy and mineral resource potential;

- studies of glacial deposits of the U.S. upper Midwest, northeast coast, and western Alpine regions that contain groundwater and building-stone resources; and

- studies of national and regional groundwater aquifers and karst sinkhole hazards.

Between 1993 and 2020, FEDMAP produced many geologic maps at 1:24,000 scale and at 1:100,000 scale. The USGS published most of these maps, and their citation records are part of the NGMDB. Additionally, FEDMAP produced a substantial number of journal publications, field trip guides, and proceedings papers.

\section{STATEMAP}

STATEMAP provides cooperative agreements with State geological surveys; the National Cooperative Geologic Mapping Act requires that States match Federal funds on an at least 1:1 basis. This part of the program focuses on new geologic maps that address societally relevant issues, as identified by the States. These issues include (1) earthquake, flood, karst, volcanic, and landslide hazards; (2) water, mineral, and energy resources; (3) soil conditions; (4) coastal resiliency; and (5) urban and infrastructure development. Examples of specific geologic mapping applications facilitated by STATEMAP funds include-

- groundwater resource studies in the glacial deposits of many Midwestern States, including Michigan, Illinois, and Iowa;

- karst sinkhole hazards and related groundwater issues in Florida, Tennessee, and other States;

- landslide hazards in Washington, Colorado, and North Carolina, tsunami hazards in Oregon and Washington, and flood hazards along major rivers and tributaries in numerous States;

- earthquake hazards and tectonic evolution in many areas, including the San Andreas Fault system in California, the Wasatch Front in Utah, the Seattle area, western Nevada, and southeastern Missouri;
- precious metal deposits in Alaska and Nevada, and industrial minerals in Alabama, Florida, Minnesota, and other States; and

- oil and gas resources in Alabama, Idaho, New Mexico, and other States.

Many States have directed STATEMAP funds into long-term projects that provide coherent geologic mapping across broad areas to address societal needs while providing a foundation for the basic understanding of a region's geologic framework. Successful geologic mapping is predicated on addressing research questions to best understand the continuity, thickness, geologic history, depositional environments, and (particularly) the extension of geologic units into areas of sparse data.

California and Illinois are demonstrable examples of STATEMAP success. In California, the long-term planning of STATEMAP projects yielded successful outcomes for various applications and advances in basic science. New detailed geologic maps prepared with STATEMAP now serve as the foundation for the development of regulatory seismic hazardzone maps (https://maps.conservation.ca.gov/cgs/information warehouse/index.html) and other derivative map products crafted by the California Geological Survey.

In the Midwest, the Illinois State Geological Survey focused on the greater Chicago and St. Louis metropolitan areas. In the Chicago region, NCGMP funds were combined with funds from the Great Lakes Geologic Mapping Coalition - an NCGMP subcomponent - to address diverse water and aggregate-resource issues.

It is important to note that most STATEMAP funds have been directed toward core geologic mapping work, with limited funds applied to complementary borehole drilling, geochronology, geochemistry, and geophysics. In some cases, important derivative maps that resulted from subsequent work have been funded through other sources. Between 1993 and 2020, STATEMAP produced more than 6,497 geologic maps at 1:24,000 scale and 858 geologic maps at 1:100,000 scale. The result is nearly 300 maps per year completed by 44 participating State geological surveys. The State geological surveys published most of these maps, and the citation records are included in the NGMDB.

\section{EDMAP}

The EDMAP component offers cooperative agreements to universities and colleges for undergraduate and graduate students to conduct geologic mapping across the Nation. In recent years, the academic geology community has shifted away from geologic mapping and fieldwork (see Whitmeyer and others, 2009); therefore, the EDMAP component provides needed support to mentor the next generation of geoscientists in modern geologic mapping and the application of field-based science for solving geologic problems. 
EDMAP projects typically include one season of fieldwork, require a 1:1 funding match from the university, and must be completed within 1 year, although short extensions are allowed. EDMAP products include geologic maps that are lead-authored by student mappers. The implementation of the EDMAP component has been through direct involvement with the academic community. Through cooperative agreements with university faculty, who serve as EDMAP principal investigators and student mentors, the NCGMP expands the research and educational capacity of academic programs by teaching students the techniques of geologic mapping and analyzing field data.

Since its inception in 1996 as a funded component of the NCGMP, 745 proposals have been supported by EDMAP funds. More than 30 individual projects were funded each year from 1996 through 2012. More recently, however, due in part to funding constraints, fewer than 27 projects per year were funded between 2013 and 2016. As of 2020 more than 170 universities have received EDMAP funding, and more than 1,335 students have gained field-based mapping experience through EDMAP projects.

\section{Renewed Vision, Mission, and Goals for the National Cooperative Geologic Mapping Program}

Geologic map coverage across the United States at scales of 1:100,000 and greater detail is incomplete, usually out of date, and not fully reconciled across map borders. At the more precise scales needed for planning, resource identification, and hazard avoidance (often 1:24,000-1:100,000), present map coverage is slightly more than 50 percent of the conterminous United States. These maps are typically unreconciled - relative to one another - due to administrative and scientific disparities and may only portray the land-surface geology with a limited number of vertical cross sections. In some regions, particularly the U.S. western interior, the percentage of adequate coverage is much lower. The associated 3D subsurface mapping, which is needed for applications such as groundwater management and sedimentary basin resource assessments, is even less complete.

The high value and compelling user needs of published geologic maps thus call for the acceleration and enhancement of geologic mapping within the United States. Pressing issues at the local, State, and national levels, related to energy, minerals, water, hazards, environment, waste, and engineering, alongside scientific research priorities, call for accelerated progress in producing a national geospatial database and similar user-friendly map products. To this end, the NCGMP puts forth the following renewed vision, mission, and goals within this 10-year strategy.

\section{The National Cooperative Geologic Mapping Program Vision}

The vision of the National Cooperative Geologic Mapping Program is to create an integrated, 3D, digital geologic map of the United States and its territories to address the changing needs of the Nation by the year 2030 .

\section{The National Cooperative Geologic Mapping Program Mission}

The mission of the National Cooperative Geologic Mapping Program is to characterize, interpret, and disseminate a national geologic-framework model of the Earth using geologic mapping and its associated research to support the responsible use of land, water, energy, and minerals, and to mitigate the effect of geologic hazards on society, thereby enhancing national security and economic growth through informed earth-resource management.

\section{National Cooperative Geologic Mapping Program Goals for a Renewed Vision}

The challenge to the National Cooperative Geologic Mapping Program is the advancement of the goals listed below in coordination with the program's FEDMAP, STATEMAP, and EDMAP components. These fundamental program goals focus on geologic mapping as a core function of the USGS within the long-term vision of mapping the Nation's geologic framework in three dimensions.

\section{Goals}

Achieve excellence in the performance and relevance of the FEDMAP, STATEMAP, and EDMAP program components, and maximize beneficial partnering between all program components.

- Fine-tune the management of NCGMP operations by optimizing efficiencies in program component functions, funding allocations, the prioritization of needs, and accountability.

- Optimize the return on program investment, capitalize on collaborative opportunities, facilitate scientific and technical intellectual exchange, and share technological advancements that boost geologic mapping efforts - coordinate, cooperate, and build valuable partnerships. 
- Acquire new geologic observations and datasets relevant to the construction of a national $2 \mathrm{D}$ and $3 \mathrm{D}$ geologic-framework model and build detailed scienceinformed models of geologic history (such as depositional environments, orogenies, and volcanism) to allow regional interpretations informed by the best available scientific understanding.

Achieve preeminence in the use of field, remote-sensing, and geophysical technologies, and construct the geospatial infrastructure required to house a variable-scale, national, integrated 2D and 3D geologic model.

- Optimize the use of field-based technology and related standards, and also expedite and expand digital fielddata capture and real-time interpretations, data preservation, and dissemination.

- Optimize the use of remote sensing, geophysical surveys, and national digital-geospatial datasets.

- Construct the infrastructure required to house a variable-scale, national, integrated $2 \mathrm{D}$ and $3 \mathrm{D}$ geologic model.

Populate the geospatial infrastructure defined under the second goal to create a variable-scale, national, integrated $2 \mathrm{D}$ and $3 \mathrm{D}$ geologic-framework model that enables the seamless construction of geologic maps within user-defined regions of interest across the United States by the year 2030.

- Undertake field observations, laboratory studies, and conceptual model development to resolve discontinuities at the boundaries between geologic provinces, and couple FEDMAP projects that have large geographic footprints with coalitions of State geological surveys (for example, the Great Lakes Geologic Mapping Coalition).

- Use remote sensing, geophysical surveys, and national digital-geospatial datasets, along with new and existing analytical tools, to extrapolate surface and subsurface geologic mapping, and thereby build subsurface and temporal 2D and 3D geologic maps and models of the Nation at variable scales and across changing geographies. Couple the NGMDB to an expanding enterprise GIS containing an integrated, nationwide geodatabase managed according to content and format specifications. The database should reconcile variable-scale county, State, regional, and national compilations of vectorized geospatial information into a national geologic-framework model. Although initially constrained to largely 2D surficial and bedrock geologic information (Phase 1), this framework model, over time, can increasingly include 2D and 3D subsurface geologic information (Phase 2). This evolving, national geologic-framework model can incorporate data that supports further iterative geologic mapping and 2D and 3D geologic modeling.

\section{Realizing the New National Cooperative Geologic Mapping Program Vision}

As needs evolve, users expect the ability to zoom between compatible digital map layers of varying resolution and query map data across broad areas. In addition, the demands on hydrogeologic, tectonic, and other modeling necessitates a focus on material properties such as lithology and hydraulic conductivity. The U.S. Geological Survey strategic plans, and a resolution unanimously passed by AASG at their 2014 Annual Meeting in Lexington, Kentucky. (Association of American State Geologists, 2014), thus emphasize the need for seamless 3D geologic maps. Bohlen and others (1998), for example, in the 2000-2010 plan for USGS geology, cited the need for basin-scale, nationally consistent maps showing the 3D distribution of hydrogeologic properties. Gundersen and others (2011), in the 2010-2020 plan for USGS geology, also called for development of the interpretations, protocols, and standards needed to provide seamless geologic maps, while foreseeing that $3 \mathrm{D}$ geologic maps of continental and offshore areas would become the standard. Bristol and others (2013), in the most recent USGS strategic planning, called for collaboration leading to (1) seamless, nationwide geologic maps; (2) 3D maps that improve the understanding of sedimentary basin processes; and (3) four-dimensional maps and models that elucidate the operation of geologic processes through time.

The AASG Lexington Resolution (Association of American State Geologists, 2014) endorsed this USGS planning and stated that adequate funding would allow the following key objectives to be achieved by 2030: (1) a vibrant pace of detailed geologic mapping, (2) regular updating, (3) nationwide, multiresolution coverage, and (4) 3D mapping to the depth of bedrock and basement, as well as a stratigraphic subdivision of sediments and little-deformed rock strata where possible. The resolution asserted that members of the AASG believe that State geological surveys should increase their commitment to work with the USGS and other partners through the NCGMP to ensure the timely provision of optimal geologic mapping. 
The urgency of user needs calls for mapping of this nature to be completed nationally, at appropriate levels of resolution, by the year 2030 and updated periodically owing to increased access, new topographic mapping, data accumulation, and real-time changes in the Earth's conditions, in addition to progress in scientific and technological methods. Geologic mapping needs to be (1) coordinated with soil mapping; (2) based on compilations of public-domain, drill-hole, and other relevant data, along with strategic new drilling and newly acquired geochronology, geochemistry, and geophysical data; (3) based on the application of sound stratigraphic naming; (4) categorized using broadly accepted terminology; (5) reconciled with offshore topographic and bathymetric data; (6) committed to regular updating; and (7) assembled as seamless statewide compilations.

Three-dimensional geologic mapping depicts the extent, thickness, and properties of strata, in support of applications such as groundwater management, engineering, and sedimentary basin resource assessments (Berg and others, 1999; Thorleifson and others, 2010; Thorleifson, 2015). Facies modeling and basin analysis guide this lithology- and properties-focused 3D mapping. This type of mapping requires the compilation of topography, bathymetry, soil mapping, 2D geologic mapping, and drill-hole data, as well as the acquisition of geophysical surveys and new drilling. Model construction, including the use of geostatistics, varies depending on resolution, complexity, data format, and data adequacy. After map units are delineated, unit properties, heterogeneity, and uncertainties can be specified. Concurrently, a basement map (for example, Precambrian rocks or as defined regionally) is needed to depict the 3D geometry of key structures, along with the quantification of basement physical properties.

In total, an urgent need exists for geologic mapping to be progressively focused on user needs while remaining flexible enough to accommodate emergent applications and new technologies. The mapping must be conducted as part of a wellplanned program based on the ongoing assessment of required databases and focused on the most detailed mapping where needed. The mapping must also be committed to jurisdictionwide completion at an appropriate level of resolution. Users require mapping accessible through open-source compatible formats for conveying subsurface mapping and linked to scanned and searchable publications, as well as geologic, geophysical, and geochemical databases. This new mapping needs to be done in a 3D format in which the extent, thickness, and properties of all sediments, rock units, and basement structures are distinguished to accommodate the needs of all users. The new mapping also needs to be based on material properties (for example, lithology) and coordinated with 3D versions of State, continental, and global-scale maps.

\section{Required Strategic Actions}

Numerous challenges and opportunities have been identified that can improve the focus and operations of the NCGMP and deliver essential earth-science information to the general public, science agencies, and decision makers. The fundamental strategic actions that address the renewed vision of the NCGMP are summarized below.

\section{Actions With Program-Wide Relevance}

- Develop and maintain an effective and detailed NCGMP implementation plan. Ensure the effective application of this strategy for the NCGMP through the construction of a continually updated plan that guides the development of the "Annual FEDMAP Prospectus" and the STATEMAP and EDMAP annual announcements. The application of this strategy thereby directs all NCGMP resources and sponsored activities toward fulfillment of the goals previously listed.

- As a starting point, commission a "National Assessment of Geologic Mapping Needs and Benefits" by way of published studies and cost-benefit analyses.

- Update and continuously maintain a database of recently completed and ongoing NCGMP-funded geologic mapping activities.

- Plan the location of NCGMP-funded projects several years in advance, such that targeted field areas can become part of consolidated requirements for lidar funding awards and can guide the development of base maps.

- Across the entire program, promote understanding and literacy in GIS, digital cartography, and information technology, and reward the ability to adapt to rapid technological changes, both for traditional 2D geologic mapping at the land surface and for subsurface mapping and eventual 3D modeling and visualization, across the entire program.

- Enable the sharing of specialized scientific expertise among the member organizations of the NCGMP community. Identify how USGS expertise can assist State geologic survey mapping projects, as was done under the COGEOMAP (Federal-State Cooperative Geologic Mapping) Program during the 1990s, and vice versa.

- Require the use of NCGMP-sanctioned standards for all maps and databases. The USGS geologic map schema (GeMS) database structure must become the universal standard for all NCGMP-funded maps. Future digital mapping techniques (DMT) workshops should be supported to continue sharing standards and technology ideas. 


\section{First Goal}

Achieve excellence in the performance and relevance of the FEDMAP, STATEMAP, and EDMAP components, and maximize the beneficial partnering between all program components.

\section{FEDMAP Specific Components}

- Establish programmatic relevance, priority areas for mapping, geologic mapping productivity, scientific quality, societal impact, and return on investment as the critical determining factors in FEDMAP implementation.

- Develop clear and transparent guidelines and procedures for evaluating FEDMAP projects and proposals and for initiating and terminating projects.

- Monitor and report the outcomes - such as maps and related products - from the FEDMAP efforts and attribute the products to FEDMAP.

- Require FEDMAP-funded projects to adhere to the standards and guidelines collaboratively developed by the USGS and AASG through the DMT workshops and coordinated by the NGMDB project.

- Support "incubator" projects started by established experts to demonstrate innovative solutions that apply to geologic mapping methodology questions so that new technologies can be integrated and derivative results that are relevant to local, regional, and national priorities can be demonstrated.

- Require FEDMAP projects to use NCGMP-endorsed standards and guidelines in the acquisition of field observations and the preparation of maps.

- Develop a means of effective and routine internal communication between all four program components coupled with an outreach to the academic community and professional societies.

- Require that all newly proposed FEDMAP projects obtain a letter of endorsement from relevant State geologists, and encourage all FEDMAP projects to present annual briefings to the relevant State geological surveys.

- Require that all FEDMAP map products are entered into the NGMDB and provided to the geological surveys of the States covered by the mapping.

- Participate in an annual AASG-convened "Geologic Mapping Forum" to review contributions on a regional basis, disseminate recent results, and encourage future collaborations.
- Collaborate with the USGS National Geospatial Program to define a set of standardized "feature extraction" products to be derived from lidar in support of geologic mapping.

\section{STATEMAP Specific Components}

- Revisit the current STATEMAP focus on 1:24,000 scale geologic maps and determine whether maps at scales smaller than 1:24,000 should be acceptable. Similarly, determine whether derivative maps and databases, at scales other than 1:24,000, or at multiple scales within a single map database, should be considered viable products.

- Streamline the cooperative agreement submittal and award process for all proposals and develop and evaluate a two-tiered cooperative agreement system, in which small proposals have a streamlined review and selection process.

- Modify the timeframe of STATEMAP-deliverable cycles to allow either 1-year or 2-year projects, and allow closer alignment with multiyear FEDMAP projects. The option for 2-year STATEMAP projects allows for more flexible field seasons and would facilitate higher quality products and increased collaboration with FEDMAP projects.

- Give a competitive advantage in the proposal process to STATEMAP projects that meet crucial State and national priorities and collaborate across program components.

- Require that STATEMAP-funded projects adhere to map and database standards and guidelines collaboratively developed by the USGS and the AASG through DMT workshops that are coordinated by the NGMDB project. The implementation of requirements would be phased in to allow time for the transition.

\section{EDMAP Specific Components}

- Establish EDMAP requirements to deliver final products to responsible FEDMAP and STATEMAP partners, thus increasing EDMAP involvement with the USGS and with State geological surveys as a recruitment tool for future hiring and to sustain strong mapping programs.

- Require that all EDMAP products be provided to the appropriate USGS program and State geological survey, submitted to the NGMDB, and made available to the public.

- Accelerate the use of social media as an EDMAP tool for communicating with former and current EDMAP students, faculty, and the geoscience student community. 
- Evaluate increasing the duration of funded EDMAP projects to 2 years and consider raising the funding limit to accommodate 2-year projects.

- Establish the career tracking of former EDMAP-funded students and use this information to develop written examples of student successes.

- Improve the communication and collaboration between academic faculty, mentors, and USGS or State geological survey staff to allow USGS and State geological survey geologists to advertise needs for potential EDMAP-funded mapping assistance. These actions can inform interested faculty about opportunities to establish collaborative work with agency geologists early in the proposal preparation process.

\section{Second Goal}

Achieve preeminence in the use of field and remote sensing and geophysical technologies, and construct the geospatial infrastructure required to house a variable-scale, national, integrated $2 \mathrm{D}$ and $3 \mathrm{D}$ geologic model.

- Require the centralized preservation of standardscompliant field data and interpretations. Regardless of the methods and technology used in the field, all useable field observations should be preserved in an archival format and stored in an enterprise GIS database for use in building a nationwide 3D geologic map database.

- Collaborate with the USGS National Geospatial Program to update topographic base maps of regions where new geologic mapping is pending.

- Adopt enterprise GIS approaches across the NCGMP community to maximize the advantages of GIS-based digital geologic mapping by allowing all participants in mapping projects to collaborate to build local, regional, and national 3D geologic map databases.

- Assess national needs for remote sensing and geophysical technologies that support geologic mapping in light of critical societal needs, such as geologic hazard identification, water quality and availability analysis, the identification of mineral and energy resources, and infrastructure development.

- Support "incubator" research pilot projects and interdisciplinary research studies that advance the use of integrated remote sensing, geophysical, and field observations to develop 3D geologic maps.

\section{Third Goal}

Populate the geospatial infrastructure defined under the second goal to create a variable-scale, national, integrated $2 \mathrm{D}$ and $3 \mathrm{D}$ geologic-framework model that enables the seamless construction of geologic maps within user-defined regions of interest across the entire United States by 2030.

- Focus NCGMP resources to drive the development of an enterprise GIS database for a national, regularly updated, well-coordinated, multiresolution, seamless, 3D geologic framework. This database should include line and point vector data representing national, regional, and detailed geologic map coverages. This database should include customized, user-friendly, traditional 2D geologic maps, 3D geologic maps and models, and various derivative map products.

- Undertake a systematic national compilation of existing published geologic maps into seamless coverage at multiple map scales and resolve nomenclature differences encountered on adjacent maps and across State boundaries.

- Develop and require the use of map standards needed to support construction of a nationwide 3D geologic map database. In order to identify additional useful standards and techniques developed elsewhere, strengthen contacts with industry associations, private consortia, and the international geoscience community.

- Establish close collaborations with other USGS programs to progress toward the completion of a reconciled, national-scale geologic map compilation, and tie NCGMP-sponsored geologic mapping directly to the studies of mineral resources, energy resources, water, and hazards.

\section{Synopsis}

The renewed NCGMP vision is prepared in anticipation of an integrated, digital, 3D geologic map of the United States and its territories that addresses the Nation's changing needs by the year 2030. Nationwide, the traditional 2D mapping of land-surface geology must certainly be completed, as per the recommendations in this report and at scales that vary appropriately by location. However, if the program's vision is to provide geologic data for the Nation, then products more complex than traditional 2D geologic maps with limited numbers of cross sections are required.

Geology is a multidimensional science that relies upon the integration of diverse datasets. These datasets necessitate cross-disciplinary interpretations of the distribution, thicknesses, and properties of materials coupled with an 
understanding of geologic unit locations within a timetransgressive continuum across a designated space. This complex vision can only be accomplished by way of a wellcoordinated geologic mapping program equipped for threeand four-dimensional mapping technology, for which the NCGMP is historically mandated.

It is noteworthy that geology is such an essential part of the everyday lives of people that it often goes unnoticed. Geologic information is fundamental to human needs because it informs the placement of infrastructure and is vital to the existence, maintenance, and persistence of society. Unfortunately, people often know little about their own geologic settings, particularly at the scale needed for meaningful and cost-effective decision making. The effect of the geologic discipline - and geologic mapping in particular - upon economic development is enormous. The clear connection to economic development is the reason governments created geological surveys in the first place.

At the national level, the NCGMP is the principal program for providing information about these issues, and the program enables decision makers to balance scientifically based land- and water-use decisions, mineral and energy resource assessments, earth-hazard evaluations, and infrastructure development with environmental and economic considerations. Moreover, natural disasters continue to occur, and the ongoing collection of geologic information allows local, State, and national leadership to understand and mitigate risks, reduce future liabilities, and address national security issues.

\section{References Cited}

Association of American State Geologists, 2014, Resolution on AASG commitment to the role of geologic mapping in society: [Lawrence, Kans.,] Association of American State Geologists Annual Meeting, 106th, Lexington, Ky., June 11, 2014, 1 p., accessed August 22, 2016, at https://ngmdb .usgs.gov/Info/docs/2014_AASG-ResolutionOnGeologicM apping.pdf.

Bernknopf, R.L., Brookshire, D.S., Soller, D.R., Mckee, M.J., Sutter, J.F., Matti, J.C., and Campbell, R.H., 1993, Societal value of geologic maps: U.S. Geological Survey Circular 1111, 53 p., accessed August 25, 2016, at https://doi.org/10.3133/cir1111.

Berg, R.C., Bleuer, N.K., Jones, B.E., Kincare, K.A., Pavey, R.R., and Stone, B.D., 1999, Mapping the glacial geology of the central Great Lakes region in three-dimensions-A model for State-Federal cooperation: U.S. Geological Survey Open-File Report 99-349, 40 p., accessed August 31, 2016, at https://doi.org/10.3133/ofr99349.
Bhagwat, S.B., and Ipe, V.C., [2000], Economic benefits of detailed geologic mapping to Kentucky: Illinois State Geological Survey Special Report 3, 39 p., accessed August 25, 2016, at https://www.ideals.illinois.edu/ bitstream/handle/2142/45219/economicbenefits03bhag.pdf

Bohlen, S.R., Halley, R.B., Hickman, S.H., Johnson, S.Y., Lowenstern, J.B., Muhs, D.R., Plumlee, G.S., Thompson, G.A., Trauger, D.L., and Zoback, M.L., 1998, Geology for a changing world-A science strategy for the Geologic Division of the U.S. Geological Survey, 2000-2010: U.S. Geological Survey Circular 1172, 59 p., accessed August 16, 2016, at https://doi.org/10.3133/cir1172.

Bristol, R.S., Euliss, N.H., Jr., Booth, N.L., Burkardt, N., Diffendorfer, J.E., Gesch, D.B., McCallum, B.E., Miller, D.M., Morman, S.A., Poore, B.S., Signell, R.P., and Viger, R.J., 2013, U.S. Geological Survey core science systems strategy - Characterizing, synthesizing, and understanding the critical zone through a modular science framework: U.S. Geological Survey Circular 1383-B, 33 p., accessed July 6, 2016, at https://oi.org/10.3133/cir1383B.

Gundersen, L.C.S., Belnap, J., Goldhaber, M., Goldstein, A., Haeussler, P.J., Ingebritsen, S.E., Jones, J.W., Plumlee, G.S., Thieler, E.R., Thompson, R.S., and Back, J.M., 2011, Geology for a changing world 2010-2020-Implementing the U.S. Geological Survey science strategy: U.S. Geological Survey Circular 1369, 68 p., accessed July 6, 2016, at https://doi.org/10.3133/cir1369.

Thorleifson, H., Berg, R.C., and Russell, H.A.J., 2010, Geological mapping goes 3D in response to societal needs: GSA Today, v. 20, no. 8, p. 27-29, accessed July 6, 2016, at https://doi.org/10.1130/gsatg86gw.1.

Thorleifson, L.H., 2015, Rationale and methods for regional 3D geological mapping programs, in MacCormack, K.E., Thorleifson, L.H., Berg, R.C., and Russell, H.A.J., eds., Three-dimensional geological mapping-Workshop extended abstracts, GSA annual meeting, Baltimore, MD, October 31, 2015: Alberta Geological Survey Special Report 101, p. 3-12, accessed August 22, 2016 at https://ags.aer.ca/document/SPE/SPE_101.pdf

U.S. Geological Survey, 2007, Facing Tomorrow's Challenges - U.S. Geological Survey Science in the Decade 2007-2017: U.S. Geological Survey Circular 1309, 67 p. [Also available at https://doi.org/10.3133/cir1309.

Whitmeyer, S.J., Mogk, D.W., and Pyle, E.J., eds., 2009, Field geology education-Historical perspectives and modern approaches: Boulder, Colo., Geological Society of America, Special Paper 461, 356 p., accessed August 22, 2016, at https://doi.org/10.1130/SPE461. 

